\author{
KAROL SAMSEL
}

Instytut Literatury Polskiej

Uniwersytet Warszawski

\title{
NORWID W CZYTELNI POLSKIEJ W PARYŻU
}

\begin{abstract}
Słowa kluczowe: Czytelnia Polska, Norwid, Czartoryski, Biblioteka Polska, Paryż, Hotel Lambert Keywords: The Polish Reading Room, Norwid, Czartoryski, The Polish Library, Paris, Lambert Hotel
\end{abstract}

\section{NORWID IN THE POLISH READING ROOM IN PARIS}

\section{S u m m a r y}

The aim of the study is to present Norwid's 'paper activity' in Paris in the light of specific rhetorical and diegetic strategies, which were 'available' for the poet in the years 1873-1875 and formed his voice of the writer and public speaker. This is how a certain area of the poet's word arises, which may be called doubly: literary and public. Norwid aims to act with words in an extreme manner quite frequently, which is enchanting on the one hand and evoking mixed feelings on the other. He employs erudition on the edge of extravagance and tests his audience, rather not accustomed to take such kinds of challenges. The years after the Siege of Paris 1870 are of particular importance here, as this is when The Polish Reading Room is becoming the democratic and people's reading room, whereas Norwid is supporting the idea of the so called natural centralisation of Polish emigrants, which is to happen, most likely, with the mediation of the Reading Room's Circle.

\section{1.}

Norwid w okresie 1873-1875 wygłosił w Czytelni Polskiej prawdopodobnie siedem wykładów. O pierwszych trzech Zofia Trojanowiczowa informuje zdawkowo: ,przypadły one na rok 1873, najprawdopodobniej na październik”, a ,ich podstawowe postulaty znamy" ${ }^{1}$. Chodzi o tzw. Centralizację działań emigracyjnych, bankowość na emigracji, zwłaszcza o stworzenie zalążka przynajmniej - sektora pożyczkowego, wreszcie - idzie również o stworzenie dziennika opinii krajowo-emigracyjnej. Zdaniem autorek norwidowskiego Kalendarza, „nie jest jasne,

${ }^{1}$ Zofia Trojanowiczowa, ,Na marginesie odczytu Norwida z roku 1875 o apatii”, Studia Norwidiana, no. 3-4 (1985-1986): 233. 
co rozumiał poeta pod pojęciem «Centralizacji»"2. Cóż, można tę mglistą dość perspektywę co najmniej w jakimś stopniu jednakowoż doprecyzować. W szerokim rozumieniu Czytelnia Polska to ,jedyne” zasługujące na to miano „ciało zbiorowe Emigracji” (X 34) $)^{3}$, ciało, które - jak wykładał swoje stanowisko Ludwikowi Nabielakowi Norwid - było w stanie wypracować na własny użytek ponadklubową, wspólnotową i emigracyjną jedność. Z relacji Mikołaja Akielewicza wynika jasno, jak istotny dla Czytelni Polskiej w październiku 1873 roku oraz później okazał się wkład słuchaczy z kręgów Stowarzyszenia Robotników Polskich. Obraz, który przywołuje w pamięci Akielewicz, to nic innego, jak prawdopodobny wizerunek Norwidowskiej widowni - słuchającej jego przemówień w roku 1873, 1874 i 1875:

Założono Czytelnię Polską, która dzisiaj liczy do 50 członków stałych, po większej części wyrobników. Są to ślusarze, kowale, rymarze, stolarze, szewcy, jubilerzy, chemicy, fabrykanci fortepianów, kapelusznicy. Najbardziej pomiędzy nimi odznacza się powierzchownością Franciszek Zaniewski, mąż poważny, z potężną siwą brodą, niegdyś podpisarz przy sądzie kalwaryjskim w Augustowskiem, a dzisiaj robotnik w zakładzie fortepianów Erarda ${ }^{4}$.

Także oni, a może i oni przede wszystkim decydowali o sukcesie planu centralizacyjnego poety. Można wnioskować, że czwarte z jego przemówień na temat znaczenia Czytelni Polskiej i emigracji z roku 1863 miało charakter szczególny.

${ }^{2}$ Kalendarz życia i twórczości Cypriana Norwida, ed. Zofia Trojanowiczowa, Elżbieta Lijewska przy współudziale Małgorzaty Pluty, vol. II: 1861-1883 (Poznań: Wydawnictwo Poznańskie, 2007), 546. Także dociekania Zofii Dambek w oddzielnym studium na ten temat nie przekonują. Jej zdaniem, potrzeba Centralizacji to konieczność „wprowadzenia swego rodzaju ceremonii [skąd jednak taka myśl? - K.S.], która by zbierała i wyjaśniała rozproszone doświadczenia powstań narodowych”. Zofia Dambek, „«Bystro czytać w dziejach», czyli o pewnym wystąpieniu Norwida w rocznice powstania styczniowego", Studia Norwidiana, no. 33 (2015): 195.

${ }^{3}$ Teksty Norwida cytuję według wydania: Cyprian Norwid, Pisma wszystkie, ed. Juliusz Wiktor Gomulicki, vol. I-XI (Warszawa: Państwowy Instytut Wydawniczy, 1971). W podanej lokalizacji liczba rzymska oznacza tom, arabska - stronę.

${ }^{4}$ Mikołaj Akielewicz, „Kronika Paryska”, Gazeta Narodowa, no. 267 (1873): 1. Jak pisze Zofia Trojanowiczowa: „Czytelnia Polska (pełna nazwa: Towarzystwo Czytelni Polskiej) rozpoczęła działalność w roku 1869, w okresie nasilającego się marazmu i rozpadu życia emigracyjnego. Pierwszy zarząd tworzyli: Leonard Chodźko, Jan Franke, Aleksander Wernicki. W roku 1872 powołano nowy zarząd, z Ludwikiem Dygatem i Wacławem Gasztowttem, wynajęto nowy lokal przy ulicy Coquillière numer 34. Odtąd działania Czytelni stały się bardziej energiczne i widoczne, przekształciła się ona w rodzaju klubu polskiego, którego celem było jednoczenie rozproszonej emigracji paryskiej pod sztandarami narodowymi, urządzanie odczytów i obchodów rocznicowych; w planach Czytelni leżało również wydawanie polskiego czasopisma”. Zofia Trojanowiczowa, „Na marginesie...”, 233-234. Inaczej niż Trojanowiczowa, uważam, że paryska Czytelnia Polska z roku 1872 nie powinna być uważana za przedłużenie Czytelni Polskiej z lat 1869-1870. W 1872 roku nie chodziło bowiem jedynie o zmianę zarządu, lecz także - o zmianę patronów całej inicjatywy, związaną z usunięciem mecenatu obozu konserwatywnego. Władysław Mickiewicz jednoznacznie wskazuje na powstanie Czytelni w 1869 roku m.in. za sprawą Leonarda Chodźki 
To wszystko - aczkolwiek nie wprost - podaje relacja cytowanego już Akielewicza. Jeżeli zaś wierzyć jego słowom, musi Norwid swoją pięćdziesięcioosobową publiczność pozostawiać $\mathrm{w}$ bardzo nietypowym wrażeniu. Twierdzi mianowicie, że „emigracja z 1863 roku jest szesnastą z rzędu”, a „pierwszym założycielem salonów, klubów i czytelni polskich na emigracji był król Stanisław Leszczyński"5. Biblijna stylizacja przemówienia zdaje się w tak skonstruowanej koncepcji emigracji dość widoczna i klarowna. Szesnaście polskich pokoleń emigracji do 1863 roku to czytelne nawiązanie do dwunastu pokoleń Izraela, polskim Izraelem zaś - jest tutaj Stanisław Leszczyński. Jeżeli uznać czwarty wykład Norwida w Czytelni Polskiej za przemówienie fasadowe, organizujące cały zamysł odczytowy poety, trzeba przyznać, że jest ono zbudowane w sposób niezwykle ryzykowny, ale i przez to imponujący. Biblijny rodowód tzw. Centralizacji to idea uderzająca swoją skalą zamysłu. W jakim więc stopniu mogli ją zrozumieć zebrani na Coquillière 34 członkowie Stowarzyszenia Robotników Polskich, czy mówiąc innymi słowy - jak postrzegali nadawcę kierowanej do siebie wypowiedzi? Co ciekawsze w tym kontekście, jak Norwid postrzegał ich - kapeluszników, szewców, stolarzy etc. - kierując do nich wypowiedź taką a nie inną, subtelnie, ale jednoznacznie nacechowaną symboliką starotestamentalną?

W swoim wąskim rozumieniu Centralizacja nawiązuje przede wszystkim do ideologii demokratyczno-ludowej oraz wyłonionej z Towarzystwa Demokratycznego Polskiego grupy naczelno-wykonawczej zwanej sekcją centralną TDP, podejmującą od 1835 roku w jej imieniu wszystkie najważniejsze decyzje. Norwid, postulując stworzenie tzw. Centralizacji naturalnej6, musiał również do tego znaczenia słowa się odwoływać. Owszem, wymownie przekształcał pojęcie wyjściowe, chciał je naturalizować, a także nasycać kontekstem biblijnym, niemniej jednak wiedział, o czym mówi i z jakiej - niesprzecznej przecież z demokratyczno-ludową, chociaż nie tożsamej z nią - pozycji występował. „Centralizacja naturalna” miała dokonywać się w łonie Czytelni Polskiej w Paryżu, gdyż, jak dawał jasno do zrozumienia Norwid w odezwie w sprawie dziennika emigracyjnego Czytelni w kwietniu 1875 roku, to ona „była pierwszą niejako próbą rozbudzenia emigracji, pierwszym usiłowaniem zbliżenia rozproszonych"7, a do tego - to już list do Ludwika Nabielaka z 1874 roku - „z niemałymi trudami i niełatwą walką

oraz Aleksandra Wernickiego, ale ostatecznie zaświadcza o jej krótkim, efemerycznym wręcz istnieniu w tym kształcie prawnym: do roku 1870. Z Czytelnią w tym właśnie kształcie Norwid nie miał zaś nic wspólnego. Władysław Mickiewicz, „Pisma emigracyjne od 1860 do 1890 roku”, in idem, Emigracja polska 1860-1890 (Kraków: Księgarnia Spółki Wydawniczej Polskiej, 1908), 136.

${ }^{5}$ Ibidem.

${ }^{6}$ Ten termin pojawia się u poety kilkakrotnie w listach do Bronisława Zaleskiego, zwłaszcza na przełomie października i listopada 1873 roku $(\mathrm{X} 13,14)$.

${ }^{7}$ Do tekstu odezwy Norwida w sprawie dziennika polskiego pierwsza dotarła Zofia Trojanowiczowa. Za: Zofia Trojanowiczowa, „Na marginesie...”, 234. 
przeciw niedołęstwu i apatii ciało to trwa i centralizuje dzienniki polskie i pewny sens publiczny" (X 35).

Równocześnie pogłębia się konflikt (mimo że nie został wcale zwerbalizowany) pomiędzy Norwidem a prasą konserwatywną, Hotelem Lambert oraz Towarzystwem Historyczno-Literackim z Biblioteką Polską. Bronisław Zaleski, zachwycony Norwidowską rozprawą „Boga-Rodzica” - pieśń ze stanowiska historyczno-literackiego odczytana, dość pospiesznie chyba deklaruje jako sekretarz „Rocznika Towarzystwa Historyczno-Literackiego” druk tekstu w piśmie. Nabywa rękopis za 150 franków, lecz ostatecznie - nie podaje go drukiem w żadnym z kolejnych numerów pisma. Rozwiązanie tej zagadki znajdujemy znów na kartach norwidowskiego Kalendarza: „wstęp do rozprawy wskazuje, że tekst był również przygotowany do publicznego wygłoszenia (być może w Czytelni Polskiej)", a to Zaleskiego jako adherenta przeciwstawnego obozu mogło bardzo wyraźnie zniechęcić. Analiza Bogurodzicy przeprowadzona przez autora Rzeczy o wolności słowa okazuje się zatem ostatecznie kolejnym, przyznajmy - dość strategicznym ogniwem projektu odczytowego Norwida w Czytelni Polskiej w Paryżu. Jego dynamikę znamionowałoby w tym wypadku istotne przejście: od toposu szesnastu pokoleń emigracji i figury szesnastego, tragicznego pokolenia roku 1863 roku do skomplikowanej interpretacji najstarszej polskiej pieśni religijnej jako narodowego „labiryntu znaczeń”... Norwid posługuje się kodem erudycyjnym i hermetycznym, co nader znamienne przed publicznością taką, jaką opisywał Akielewicz.

Kto więc drukuje lub sprawozdaje przemówienia Norwida z Czytelni Polskiej w Paryżu? To symptomatyczne - przede wszystkim zachowawcza bądź umiarkowanie demokratyczna prasa lwowska i liberalno-ziemiański „Dziennik Poznański”. Płomienne przemówienie poety w rocznicę powstania listopadowego 29 listopada 1875 roku, w kolejności przemówień w Czytelni szóste ma zostać przedrukowane we lwowskiej „Gazecie Narodowej”, a sprawozdanie z ostatniego, siódmego odczytu Norwida dotyczącego apatii przekazują swoim czytelnikom zarówno lwowski „Dziennik Polski”, jak i „Dziennik Poznański”9.

2.

W aspekcie omawianej tutaj dynamiki rozwoju problematyki odczytów Norwida właśnie wykłady szósty - o powstaniu styczniowym i siódmy - o apatii stanowią apogeum rozwoju stylu, metod i strategii wykładania idei przez poetę. Pierwszy istnieje w postaci zapisanej, drugi - nie zachował się do dzisiaj. Spróbujmy mimo to na równych prawach dokonać syntezy obydwu z wygłaszanych tu przez poetę tekstów.

\footnotetext{
${ }^{8}$ Kalendarz..., vol. II: 1861-1883, 549.

${ }^{9}$ Ibidem, 583, 604-606.
} 
Pierwszy - szczególnie w oczach lwowskich korespondentów - jawi się jako niekwestionowany triumf Norwida nad materią słowa mówionego. Drugi - jest już w oczach Lwowian tekstem sygnalizującym erudycyjny dystans przemawiającego do publiczności, który teraz jak gdyby odstępował od pełnionej do tej pory funkcji retora publicznego i wyraziciela prawd ogółu i ostatecznie... przygotowywał filozoficzną dysertację. O ile tak nakreślona rozprawa lwowski „Dziennik Polski” rozczarowuje, o tyle imponuje ona i pobudza do twórczej refleksji korespondentów poznańskich, w tym Wacława Gasztowtta. Przyjdzie nam zresztą do tego jeszcze wrócić, to bowiem chyba w najmniejszym stopniu przypadkowe nie jest, że Norwidowski tekst o kompleksie apatii narodowej inkrustowany erudycyjnymi odwołaniami do filozofii Arthura Schopenhauera, niezrozumiałymi z pewnością dla przeciętnego słuchacza Czytelni, właśnie Gasztowtta mógł poruszyć. Gasztowtt bowiem, wychowanek i jeden z kierowników szkoły batignolskiej oraz promotor kultury polskiej we Francji, sam w tym okresie wygłosił jeden $\mathrm{z}$ istotniejszych $\mathrm{w}$ pierwszych latach historii Czytelni Polskiej odczytów: 2 kwietnia 1876 roku pod tytułem Poezja polska i francuska wXIX wieku.

To nota bene niezwykle istotny trop w badaniu możliwych inspiracji Norwida francuskim modernizmem, chociaż nie wiemy, czy Norwid był słuchaczem tego akurat odczytu, a zarazem wiemy doskonale, że wobec pokoleń Théophile'a Gautiera i Charles'a Baudelaire'a Gasztowtt zachowywał znamienną rezerwę. Nie mamy pojęcia co prawda, czy zostali oni wymienieni z nazwiska, poznański korespondent jednak przynajmniej wycinkowo zaznaczył sąd prelegenta na ich temat. Polak miał „wątpić” co najmniej, „czy wysoko wzbije się lot poczynającego się dziś pokolenia francuskiego, które przede wszystkim dba tylko

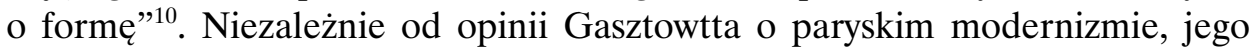
wykład potwierdzał niesprawiedliwość złośliwych docinków krążących wokół Czytelni o „Polakach znowu pomieszanych na odczytach, gdzie doktor jeden czyta o niepokalanym poczęciu, a ksiądz o krążeniu krwi”" Ci „pomieszani” Polacy rozprawiali - jak się zdaje - bardzo otwarcie o przełomowym wymiarze epoki, w której żyli i funkcjonowali.

Przemawiając w rocznicę powstania styczniowego, Norwid okazywał się „niezaprzeczenie mistrzem w sztuce publicznego mówienia”, „uderzał treściwością, a cały jego artyzm polegał na estetycznym streszczeniu i wykwintnym wiązaniu myśli, że przemowa jego była całym szeregiem obrazów, składających się na jeden

\footnotetext{
${ }^{10}$ Wacław Gasztowtt, „Poezja polska i francuska w XIX wieku”, Dziennik Poznański, no. 87 (1876): 2.

${ }^{11}$ Zygmunt Mineyko, Z tajgi pod Akropol. Wspomnienia z lat 1848-1866, ed. Eligiusz Kozłowski, Kazimierz Olszański (Warszawa: Instytut Wydawniczy „Pax”, 1971), 539. Sąd Mineyki przywołuję również z tego względu, że powołuje się na niego jako na wiążący Dambek. Zofia Dambek, „«Bystro czytać...»”, 194.
} 
uderzający całością swoją mistrzowski obraz"12 - tak przynajmniej twierdził o nim korespondent lwowskiej „Gazety Narodowej”. Jeżeli szósty wykład miał zauroczyć, a może raczej - oszołomić słuchaczy, siódmy i ostatni miał charakter niezwykle kameralny i wewnętrznie wystudiowany, wręcz wyciszony. Poeta nie dbał o komfort zrozumienia dla swoich słuchaczy, jak gdyby pozwalając, aby nieusuwalne różnice między nim a publicznością Czytelni Polskiej ujawniły się w końcu z całą swoją ostrością. Po pierwsze - był Norwid erudycyjny, aż do granic swojego hermetyzmu. Po drugie - pozostawał apodyktyczny oraz wymagający jako wykładowca. Słuchacze, zwłaszcza ci lwowscy, których odbiór poznaliśmy ze sprawozdań, odchodzili z uczuciem rozczarowania i niezrozumienia:

Pan Cyprian Norwid przeczytał uczoną rozprawę o apatii ze stanowiska moralno-politycznego. Słuchaliśmy jej z natężonym umysłem, bo tak oryginalnych, tak jędrnych, i głębokich myśli rzadko spotkać można na obchodach publicznych. Wszakże rozprawa p. Norwida jest czysto filozoficznej natury. Założenie, że apatia jest naturalną, wrodzoną, ale że człowiek ma w sobie siłę oddziaływania przeciw niej zwycięsko, popartym było analizą duszy ludzkiej i wybitnymi przykładami. Nam jednak potrzeba było coś więcej. Nam należało powiedzieć o naszej własnej apatii i wykazać, że apatia sąsiaduje ze śmiercią, że prowadzi do samobójstwa, niegodnego człowieka w ogólności, a tym bardziej Polaka [...]. Rozprawa p. Norwida byłaby może na miejscu w akademii uczonych, na obchodzie rocznicy listopadowej wydała się jakby nieskończonym jeszcze ustępem do dzieła o apatii [podkr. moje - K.S.] ${ }^{13}$.

Warto przyjrzeć się tej relacji jako dokumentacji erozji Norwidowskiego wizerunku. Czy bowiem Apatia ze stanowiska narodowo-politycznego, niezachowany, ostatni wykład Norwida w Czytelni Polskiej w Paryżu odbyty 29 listopada 1875 roku w kolejną z rocznic powstania listopadowego nie dowodzi głębokiego kryzysu zbudowanej przez poetę figury, bardzo specyficznie wykreowanego wizerunku Norwidowskiej osoby publicznej? Siódmy wykład o apatii jest naturalną kontynuacją wykładu szóstego, w którym - jak uważał Wiktor Weintraub - o powstaniu styczniowym explicite Norwid wyłącznie wzmiankowa ${ }^{14}$. W 1875 roku w ostatnich wykładach w Czytelni Polskiej w Paryżu poeta zatem więcej przemilcza niż wypowiada. Wielki, zaplanowany przez niego projekt zostaje $\mathrm{w}$ ten sposób zamknięty wcześniej niż ktokolwiek by to zakładał. Ale nie zostaje urwany. Norwid - cokolwiek by mówić o tworzonych przez niego wystąpieniach - dba o efektowność zwieńczenia serii swych siedmiu wypowiedzi. W kolejną z rocznic insurekcyjnych, podczas kolejnego z tradycyjnych, rocznicowych odczytów przekształca się w filozofa i nakazuje wszystkim zebranym emigrantom

${ }^{12}$ A., „Korespondencje Gaz. Nar. Paryż d. 23 stycznia”, Gazeta Narodowa, no. 24 (1875): 2. Pod jednoliterowym pseudonimem autorki norwidowskiego Kalendarza dopatrują się Stanisława Konwickiego. Kalendarz..., vol. II: 1861-1883, 583.

${ }^{13}$ Dziennik Polski, no. 283 (1875). Cit. per Kalendarz..., vol. II: 1861-1883, 606-607.

${ }^{14}$ Wiktor Weintraub, „Norwid wobec powstania styczniowego”, Studia Norwidiana, no. 12-13 (1994-1995): 15. 
- od gryzipiórków przez jubilera i kapelusznika aż po filantropa i polistopadowego weterana - zanurzyć się w „sfery spekulacyjne”, jak relacjonuje wykład Gasztowtt i poddać się bezinteresownej medytacji filozoficznej. W ten sposób ostatni wykład Norwida, ostatnie ogniwo autorskiego, wykreowanego przez niego projektu, staje się szczególnego rodzaju traktatem - traktatem filozoficznym z Schopenhauerem w tle. To wszystko, co zostało zapoczątkowane sugestią podobieństwa pomiędzy polskimi pokoleniami emigracyjnymi a dwunastoma plemionami Izraela, zakończone zostaje zupełnie kontradyktorycznie, lecz i jednocześnie - olśniewająco: oskarżeniem emigrantów o nirwanizm w duchu Schopenhauera. Jak streszcza całość Gasztowtt:

\begin{abstract}
Przedmiot był bardzo stosownie obranym; apatia czyli obojętność, jednoznacząca z schopenhauerowskim pesymizmem, dla którego szczytem szczęścia jest zniszczenie wszelkiej działalności, indyjska nirwana, dziś jest powszechną chorobą. A jeśli który naród - to nasz w obecnej chwili, jeżeli jaka część społeczeństwa polskiego - to właśnie emigracyjna, ulega tej chorobie. P. Norwid umiał streścić w poglądzie historycznym i filozoficznym wszystkie objawy apatii, badać jej różne przyczyny, wykazać środki zaradcze i lekarstwa na tę niszczącą wszystkie siły żywotne plagę naszych czasów. Poetyczne porównania, uczone wywody, satyryczne opisy, trafne spostrzeżenia, głębokość poglądów filozoficznych robią z tego odczytu jeden z najoryginalniejszych utworów, jakie nam było kiedy słyszeć ${ }^{15}$.
\end{abstract}

Szacunku Norwida do instytucji czytelni polskiej, a nawet przedkładania czytelń nad biblioteki, instytucje „pierwszego głosu” i „głównego nurtu” nie da się łatwo zawęzić do jednego, ograniczonego - „paryskiego” przypadku. Zanim jeszcze w orbicie zainteresowania autora Promethidiona pojawiła się Czytelnia Polska w Paryżu, 24 kwietnia 1854 roku na zebraniu Towarzystwa Demokratycznego Wygnańców Polskich w nowojorskiej Czytelni Polskiej przy Laurens Street 141 został odczytany tzw. amerykański „,skład zasad” Norwida ${ }^{16}$. Po raz kolejny w ten sposób casus obywatelstwa Norwida zyskał swoją realizację w obliczu publiczności szczególnego rodzaju: widowni Czytelni Polskiej na drugim kontynencie, widowni, dodajmy, nieprzypadkowej, albowiem politycznej - członków amerykańskiego odłamu londyńskiej Centralizacji umiarkowanych demokratów Stanisława Worcella, niegdyś związanego z Towarzystwem Demokratycznym Polskim ${ }^{17}$.

${ }^{15}$ Wacław Gasztowtt, „Korespondencje Dziennika Pozn. Paryż 26 listopada”, Dziennik Poznański, no. 278 (1875): 2.

${ }^{16}$ Kalendarz..., vol. I: 1821-1860, 552. Cf. Zofia Dambek, Elżbieta Lijewska, Joanna Piątek-Swat, „Amerykański «Skład zasad» Norwida?”, Tygodnik Powszechny, no. 32 (2002).

17 „In 1853 about 150 of the more radical Polish émigrés founded in New York City the Towarzystwo Demokratyczne Wygnańców Polskich w Ameryce [Democratic Society of Polish Exiles in America], a branch of Stanisław Worcell's Centralisation of Polish Democrats based in London”. James S. Pula, „The Civil War and the January Insurrection”, in idem, Polish Americans. An Ethnic Community (Woodbridge: Twayne Publishers, 1995), 9. 
3.

Norwid w Czytelni Polskiej w Paryżu - mimo że w dużym stopniu to figura wyobrażona - stanowi postać niezwykle norwidologii potrzebną. Mimo niedostateczności źródeł, a także skazania (w pewnych przypadkach) wyłącznie na sprawozdania w prasie lwowskiej, poznańskiej czy „Dzienniku Polskim”, hipotezy na temat tego zakresu aktywności Norwida rzucają nowe światło zarówno na jego twórczość, jak i na dojrzały światopogląd. Zsumowanie dostępnych informacji z kolei bardzo jaskrawo rzutuje na pojęty szeroko fenomen późnego Norwida. Całość wiedzy nadaje pisarzowi aurę o tyle wybitną, co ekstrawagancką. Tylko tak prawdopodobnie można wytłumaczyć oraz przybliżyć obraz poety głoszącego odczyt przed publicznością wszelkich zawodów, w tym nade wszystko - przed polską publicznością robotniczą w Paryżu, w nim zaś łączącego karkołomnie Schopenhauera z Biblią, usiłującego naprędce stworzyć bicz na Schopenhaeurowski nirwanizm. Wszystko to z kolei ma mieć miejsce - rzecz równie warta tu pamiętania - w trakcie obchodów kolejnej rocznicy powstania listopadowego.

Można pozazdrościć autorowi Assunty zarówno śmiałości, jak i wyobraźni razem z erudycją, lecz nade wszystko - należy podkreślić gigantyczne aspiracje Norwida, które wymownie wysadzają go z ram obowiązującej go konwencji odczytowej. Czytelnia Polska w Paryżu postrzegana jest z perspektywy zwolenników obozu czartoryszczyków jako klub polityczny i te ramy działalności formalnie możemy także przypisać Norwidowi. Nie sposób jednakże nie wskazać w tych okolicznościach na to, jak poeta poza owe społeczno-polityczne warunki wykraczał, tworząc idiomatyczny projekt publicystycznej aktywności intelektualnej. W jej ramach - porzucając bezpieczne zaplecze odczytującego - realizował uderzająco wiele celów, nieraz trudnych do objęcia naraz przez umysły słuchaczy oczekujących od mówcy przede wszystkim jasności wyrażenia (co widać dobitnie na przykładzie wzbudzającego największą konsternację odczytu ostatniego na temat narodowej apatii, wygłoszonego w 1875 roku, ale niestety niezachowanego).

Nie jest więc istotne tylko to, czy mamy w tym wypadku do czynienia z Norwidem-demokratą albo antagonistą Hotelu Lambert. Nie jest ważne jedynie to, czy i w jaki sposób członkowie Czytelni Polskiej w Paryżu, w tym społeczność robotnicza - stawaliby się lustrem, w którym przegląda się Norwid lub które Norwid rozbija. Zasadnicze wydaje mi się tutaj nade wszystko nakreślenie horyzontu tej odmiany aktywności poety, ukazanie, że jest ona celowa i spójna w założeniach, co nie oznacza jeszcze, że jest ona całościowym projektem integracji pierwszego w Paryżu pokolenia polskich emigrantów z pokoleniem drugim. Norwidowskie odczyty publiczne 1873-1875 to z pewnością nie sekwencja przypadkowych epizodów. Przeczy temu wyprzedzający paryskie wystąpienia o bez mała dwadzieścia lat, nowojorski odczyt poety nazwany przez Zofię Dambek 
oraz Elżbietę Lijewską Norwidowskim „składem zasad”. Wielka zatem szkoda, że to, co wydarzyło się później w Paryżu, jest całością niedającą się żadnymi sposobami rekonstruować - może poza kilkoma dostępnymi, nielicznymi na jej temat przekazami na łamach krajowej prasy...

\section{Bibliografia}

A. „Korespondencje Gaz. Nar. Paryż d. 23 stycznia”. Gazeta Narodowa, no. 24 (1875). Akielewicz, Mikołaj. „Kronika Paryska”. Gazeta Narodowa, no. 267 (1873).

Dambek, Zofia. „«Bystro czytać w dziejach», czyli o pewnym wystapieniu Norwida w rocznicę powstania styczniowego", Studia Norwidiana, no. 33 (2015).

Gasztowtt, Wacław. „Korespondencje Dziennika Pozn. Paryż 26 listopada”. Dziennik Poznański, no. 278 (1875).

Gasztowtt, Wacław. „Poezja polska i francuska w XIX wieku”. Dziennik Poznański, no. 87 (1876).

Kalendarz życia i twórczości Cypriana Norwida, ed. Zofia Trojanowiczowa, Elżbieta Lijewska, Małgorzata Pluta, vol. II 1861-1883. Poznań: Wydawnictwo Poznańskie, 2007.

Mineyko, Zygmunt. Z tajgi pod Akropol. Wspomnienia z lat 1848-1866, ed. Eligiusz Kozłowski et Kazimierz Olszański. Warszawa: Instytut Wydawniczy „Pax”, 1971.

Norwid, Cyprian. Pisma wszystkie, ed. Juliusz Wiktor Gomulicki, vol. I-XI. Warszawa: Państwowy Instytut Wydawniczy, 1971.

Trojanowiczowa, Zofia. „Na marginesie odczytu Norwida z roku 1875 o apatii”. Studia Norwidiana, no. 3-4 (1985-1986).

Weintraub, Wiktor. „Norwid wobec powstania styczniowego”. Studia Norwidiana, no.12-13 (1994-1995). 